\title{
Betting on the Wrong (Trojan) Horse: CSR and the Implementation of the UN Guiding Principles on Business and Human Rights
}

\author{
Florian WETTSTEIN $\llbracket * *$
}

\begin{abstract}
Ten years after the publication of the United Nations Guiding Principles on Business and Human Rights (UNGPS), implementation efforts are in full swing. Companies in particular have used their existing corporate social responsibility (CSR) structures to make sense of and implement Pillar II of the UNGPs. This process has led to a co-optation of the business and human rights (BHR) agenda. One manifestation of such co-optation is the instrumentalization of CSR to confront and undermine the growing trend towards binding BHR legislation. Accordingly, this contribution conceptualizes Pillar II implementation as a process of domestication, co-optation and confrontation of the BHR agenda. It makes sense of this process by juxtaposing it with longstanding critique against CSR put forth particularly by critical management scholars, raising the question whether CSR is indeed well-equipped to drive BHR implementation efforts within companies.
\end{abstract}

Keywords: co-optation, corporate responsibility, critical management studies, CSR, human rights due diligence, UNGPs

\section{INTRODUCTION}

The year 2021 marks the tenth anniversary of the publication of the United Nations Guiding Principles on Business and Human Rights (UNGPs). Or put differently, it brings the first decade of implementation efforts of the UNGPs to a close. Back in 2011, the UNGPs were received with maximum credit: they were endorsed unanimously by the UN Human Rights Council and enjoyed the support of countless governments and of large parts of the private sector. Even the International Organisation of Employers and the

II Conflicts of interest: The author was a member of the steering committee of the Swiss Responsible Business Initiative 2015-2020.

* University of St Gallen - Institute for Business Ethics, St Gallen, Switzerland.

Funding statement: The research or writing of this manuscript has not been funded or commissioned by third parties. 
International Chamber of Commerce explicitly endorsed the UNGPs - a remarkable turnaround, considering that not even ten years earlier, these two organizations were among the fiercest opponents of the UN Draft Norms, the then UN Sub-Commission on Human Rights' proposal for a legally binding international framework for corporate human rights obligations. ${ }^{1}$ While civil society organizations were less enthusiastic and criticized the lack of bindingness and enforcement of the UNGPs, they too welcomed them as a step forward, if only a small one.

However, looking back at the first decade of implementation yields ambiguous results. On the one hand, countless initiatives and implementation efforts in all sectors - private, governmental and civil society - have brought the UNGPs alive in policy and practice. On the other hand, this has not yet significantly improved the situation of those whose human rights are most severely impacted by corporate activities on the ground. It is this discrepancy between ambition and results that has recently led to a shift in implementation measures from predominantly voluntary initiatives to a push towards binding legislation. Along with this shift, the seeming harmony between actors, expressed through the widespread endorsement of the UNGPs in 2011, is dissipating and old controversies are starting to reappear. Within this controversy, the role of corporate social responsibility (CSR) seems of particular interest. Having been one of the main drivers of the business and human rights (BHR) agenda in the early stages of the implementation process, CSR has increasingly come to serve as a defence for corporations against the call for BHR legislation; put bluntly, CSR seems to have gone from friend to foe of the BHR agenda.

This contribution attempts to capture this changing role of CSR and make conceptual sense of it, raising the question whether CSR is indeed well-equipped to drive BHR implementation efforts within companies.

The argument proceeds as follows. Section II reflects on the implementation efforts with regard to Pillar I of the UNGPs and outlines the increasing trend towards mandatory legislation. Section III looks at Pillar II implementation and particularly at the changing role of CSR in the process of the above-mentioned shift. It conceptualizes implementation of Pillar II as a process of domestication, co-optation and confrontation of the BHR agenda and illustrates some of the insights by example of the Swiss Responsible Business Initiative (RBI). Section IV puts the conceptual findings in relation with long-standing critique against CSR put forth particularly by critical management scholars. Section V concludes.

\section{Waking UP From the NAP: A Decade of Pillar I Implementation}

The UNGPs rest on three pillars: the first pillar is the state duty to protect human rights from corporate and third-party abuse, which is grounded in international law. The second pillar is the corporate responsibility to respect human rights, which is grounded in social expectations. The third pillar aims at the improvement of victims' access to remedy. It is

1 David Weissbrodt and Muria Kruger, 'Norms on the Responsibilities of Transnational Corporations and other Business Enterprises with Regard to Human Rights' (2003) 97 American Journal of International Law 901. 
to be interpreted both as a part of the state duty to protect and of the business responsibility to respect human rights.

In terms of Pillar I implementation, the UNGPs call on states to use a 'smart mix' of measures, understood as a balanced approach consisting of national and international as well as voluntary and mandatory instruments. In what we could call a first phase of implementation in the years following the publication of the UNGPs, National Action Plans (NAPs) on business and human rights became the main instrument through which states outlined the shape and trajectory of their respective set of instruments and measures for the years to come. As policy tools, NAPs are not a novel invention, but have been known and used in other policy areas, from which they were adapted to the BHR domain. The purpose of NAPs is to provide strategic orientation, outline priorities and specific measures and activities to implement state obligations and policy commitments. ${ }^{2}$ When the European Commission called on its member states to develop NAPs for the implementation of the UNGPs - a call that was reinforced by the UN Human Rights Council in $2014^{3}$ - NAPs quickly became the focal point of early implementation efforts. ${ }^{4}$ The first NAPs were released in 2013 by the governments of the UK and the Netherlands. About two dozen countries followed suit in the following years and countless others are currently in the process of or have taken concrete steps towards developing a NAP. The UN Working Group on Business and Human Rights (UNWG) also actively promoted NAPs during this first phase of implementation. ${ }^{5}$

While NAPs have been important with regard to committing governments to put and keep BHR on their policy agenda, it is safe to say that by and large, they have remained rather vague, non-committal and predominantly declaratory in nature, outlining existing measures and policies, rather than committing to new ones. ${ }^{6}$ Thus, despite the UNGPs' explicit recommendation to implement a smart mix of both voluntary and mandatory measures, governments have avoided explicit commitments to new legislation in their NAPs almost across the board. ${ }^{7}$

Against this background, it is of little surprise that this reluctance of governments to commit to the whole spectrum of hard and soft measures was answered by growing civil society movements and campaigns, which have been pushing for mandatory BHR legislation in a second phase of implementation. This push happened both at the international and the national levels. At the international level, the delegations of

\footnotetext{
2 Claire Methven O'Brien, Amol Mehra, Sara Blackwell and Cathrine Bloch Poulsen-Hansen, 'National Action Plans: Current Status and Future Prospects for a New Business and Human Rights Governance Tool' (2016) 1:1 Business and Human Rights Journal 115, 118; Working Group on Business and Human Rights, 'Guidance on National Action Plans on Business and Human Rights' (Geneva: UN Working Group on Business and Human Rights, 2016).

3 Methven O'Brien et al, note 2.

4 Humberto Cantú Rivera, 'National Action Plans on Business and Human Rights: Progress or Mirage?' (2019) 4:2 Business and Human Rights Journal 213, 216-217; Damiano De Felice and Andreas Graf, 'The Potential of National Action Plans to Implement Human Rights Norms: An Early Assessment with Respect to the UN Guiding Principles on Business and Human Rights' (2015) 7:1 Journal of Human Rights Practice 40, 42.

5 Working Group on Business and Human Rights, note 2.

6 Methven O'Brien et al, note 2, 118.

7 One notable exception is the German NAP, which announced to introduce legislation, if not a majority of companies would implement human rights due diligence on a voluntary basis by 2020 . An assessment in 2020 revealed that only about one-fifth of companies had complied. As a consequence, the German government has announced to introduce legislation in 2021.
} 
Ecuador and South Africa, supported by hundreds of civil society groups and organizations, moved a resolution before the UN Human Rights Council to enter new negotiations for a BHR treaty. The resolution was adopted in 2014 and treaty deliberations commenced in $2015 .^{8}$ However, while the road to a treaty is generally long and the prospects of the specific negotiations remain highly uncertain to this day, the more impactful developments, at least in the short run, are currently happening at the domestic level, where movements supporting national BHR legislation can be observed in a growing number of countries, particularly in Western Europe. As a result, a number of countries have already adopted legislation containing human rights due diligence obligations in recent years. As such, they have contributed to what has been called a continuous 'hardening' of the UNGPs or certain parts thereof. ${ }^{9}$

The most comprehensive and far-reaching law was adopted in France in 2017. The French Duty of Vigilance Law establishes a human rights due diligence obligation for large French companies and opens channels for civil litigation against offending companies. ${ }^{10} \mathrm{It}$ quickly became the international reference point for such legislation. A narrower law focusing specifically on child labour has been adopted in the Netherlands. However, a more comprehensive and general mandatory human rights due diligence law is currently being discussed there as well. A reporting measure containing a human rights due diligence obligation for companies with regard to child labour and conflict minerals is set to be adopted in Switzerland, and Germany has also presented a proposal for mandatory human rights due diligence legislation. In various other countries there are concrete campaigns and movements pushing towards the adoption of such legislation. Above all, the European Union's announcement to follow suit and propose BHR legislation for all member states in 2021, will likely become the real 'game changer' in this regard and firmly establish the push for mandatory human rights due diligence as an international legislative trend. ${ }^{11}$

\footnotetext{
8 On the business and human rights treaty, see Surya Deva and David Bilchitz (eds.), Building a Treaty on Business and Human Rights: Context and Contours (Cambridge: Cambridge University Press, 2017); Doug Cassell and Anita Ramasastry, 'White Paper: Options For a Treaty on Business and Human Rights' (2016) 6:1 Notre Dame Journal of International \& Comparative Law 1; Olivier De Schutter, 'Towards a New Treaty on Business and Human Rights' (2016) 1:1 Business and Human Rights Journal 41; David Bilchitz, 'The Necessity of a Business and Human Rights Treaty' (2016) 1:2 Business and Human Rights Journal 203; Nadia Bernaz and Irene Pietropaoli, 'Developing a Business and Human Rights Treaty: Lessons from the Deep Seabed Mining Regime Under the United Nations Convention on the Law of the Sea' (2020) 5:2 Business and Human Rights Journal 200.

9 Barnali Choudhury, 'Hardening soft law initiatives in business and human rights' in Jean J du Plessis and Chee Keong Low (eds.), Corporate Governance Codes for the 21st Century (Cham, Switzerland: Springer, 2017); Burkard Eberlein, 'Who Fills the Global Governance Gap? Rethinking the Roles of Business and Government in Global Governance' (2019) 40:8 Organization Studies 1125. Abraham Newman and David Bach, 'The European Union as Hardening Agent: Soft Law and the Diffusion of Global Financial Regulation' (2014) 21 Journal of European Public Policy 430. Jette Steen Knudsen and Jeremy Moon, Visible Hands: Government Regulation and International Business Responsibility (Cambridge: Cambridge University Press, 2017).

10 Sandra Cossart, Jérôme Chapelier and Tiphaine Beau de Lomenie, 'The French Law on Duty of Care: A Historic Step Towards Making Globalization Work for All' (2017) 2:2 Business and Human Rights Journal 317; Elsa Savourey and Stéphane Brabant, 'The French Law on the Duty of Vigilance: Theoretical and Practical Challenges Since its Adoption' (2021) 6:1 Business and Human Rights Journal 141.

11 For an overview of BHR laws and respective initiatives, see Business \& Human Rights Resource Centre, 'National \& regional movements for mandatory human rights \& environmental due diligence in Europe', https://www.businesshumanrights.org/en/latest-news/national-regional-movements-for-mandatory-human-rights-environmental-due-diligencein-europe/ (accessed 11 April 2021), and Business \& Human Rights in Law, 'Key Developments', http://www.bhrinlaw.org/ key-developments (accessed 11 April 2021).
} 
This shift in tune of Pillar I implementation from soft, non-committal NAPs to mandatory human rights due diligence campaigns in a growing number of countries has led to changing constellations also with regard to the implementation of Pillar II. In particular, it has exposed CSR as a questionable frame when it comes to a coherent and holistic implementation of a BHR agenda that is truly aligned with the UNGPs.

\section{Pillar II Implementation as a Process of Domestication, Co-Optation and Confrontation}

The UNGPs formulate both foundational as well as operational principles for all three pillars. The foundational principles of Pillar II establish and define the corporate responsibility to respect human rights. To meet their responsibility, corporations ought to implement a human rights due diligence process in order to identify, prevent, mitigate and account for how they address their human rights impacts. The operational principles and particularly the commentaries accompanying them specify this process, for example, with regard to the integration of human rights due diligence processes in existing enterprise risk management systems. However, the operational principles also remain rather broad and general in nature without providing much specific instruction on implementation. Thus, within the parameters provided by the UNGPs, corporations enjoy ample discretion with regard to the implementation of the provisions.

\section{A. Domestication}

A couple of years after the publication of the UNGPs, John Ruggie observed 'encouraging' signs of companies responding to the UNGPs. ${ }^{12}$ While a study he conducted revealed a shortage of 'stand-alone approach[es]' that companies would adopt to address and implement their human rights responsibility, ${ }^{13}$ it did record an expansion of voluntary initiatives addressing human rights overall, which was facilitated not least 'by rapidly expanding CSR staffs within companies' as well as the emergence of a supporting industry and broad dissemination efforts by entities like the UN Global Compact. ${ }^{14}$ Thus, early on and perhaps not surprisingly, the dominant approach chosen by companies to implement the UNGPs was through their existing CSR structures with CSR departments in charge of the process.

Ruggie's early insights on implementation of the UNGPs also seem to be confirmed by more recent research. Obara and Peattie's study, for example, showed that companies with existing CSR structures, processes and mechanisms primarily used those channels to make sense and clarify the meaning of human rights requirements. ${ }^{15}$ Also with regard to

\footnotetext{
12 John G Ruggie, Just Business: Multinational Corporations and Human Rights (New York; London: W. W. Norton \& Co, 2013) 75-76.

13 Ibid, 76.

14 Ibid, 75-76.

15 Louise J Obara and Ken Peattie, 'Bridging the Great Divide? Making Sense of the Human Rights-CSR Relationship in UK Multinational Companies' (2016) 53:6 Journal of World Business 781.
} 
implementation, such companies tend to view human rights 'as an integral part of CSR' ${ }^{16}$ :

for most of the sample companies, CSR represented a significant field of past learning that shaped the development and management of HR [Human Rights] within companies. This is not to imply that other factors were unimportant, but that CSR represented a clear organizational-level 'frame' (the retained knowledge and 'memory' of the organization) that directly influenced when companies noticed HR and how these commitments were then organized and implemented. ${ }^{17}$

Thus, CSR has served as a device both with regard to making sense of, as well as for the operationalization and implementation of, human rights, which for many companies appeared to raise new and abstract demands. In that sense, companies have tended to pursue what we can call a domestication of BHR demands through the logic and rationale of existing CSR structures.

At the time of conducting their study, Obara and Peattie were inconclusive about the practical effects of such a process of domestication and 'whether adapting HR within CSR helps to promote the implementation and reach of the commitments, or whether HR becomes less visible and effective when addressed within CSR rather than through an explicit HR focus and language.' ${ }^{18}$ Judging whether and how such a domestication affects the protection and realization of human rights, as they state, was difficult as 'of those that had implemented HR, most were in the early stages of this process and had yet to fully appreciate and measure their HR impact.' ${ }^{19}$ It seems that after a full decade of implementation, the drawbacks of this predominant approach are becoming more clearly visible today.

\section{B. Co-optation and Confrontation}

The second phase of implementation with its push for human rights due diligence legislation changed the implementation dynamic. In contrast to their previous facilitating role, companies have become increasingly confrontational, voicing resistance against more binding measures. This may not be surprising, for corporations rarely take a welcoming or proactive stance with regard to proposed new regulations. However, the UNGPs themselves, which many of those same companies have claimed to be supportive of, clearly and expressly refer to BHR legislation as a necessary part of a smart mix of measures. What seems interesting in this particular instance is that CSR itself has become a reference point for companies' resistance and opposition. Commonly, arguments against new domestic business regulation tend to emphasize its alleged negative impact on companies' competitiveness in the global marketplace, the danger of companies dislocating elsewhere and the associated loss of jobs and the ripple effect on other businesses. While such objections also loom large in the discussion on BHR

\footnotetext{
Ibid, 9.

Ibid, 12 .

18 Ibid, 12

19 Ibid, 9.
} 
legislation, key arguments increasingly centre on the threat that such legislation is allegedly posing to companies' CSR engagement. Because CSR has become the key avenue for BHR implementation, such legislation is said to be counter-productive to the very BHR agenda that it tries to promote. Thus, opposition against BHR legislation is presented as emanating from companies' own genuine concern for human rights and framed as an attempt to save the BHR agenda from itself.

As argued above, CSR did not only provide a 'toolbox' for implementation, but more holistically and perhaps more pervasively an overall frame and language to domesticate human rights, which for many companies appeared as overly conceptual, abstract and confusing. ${ }^{20}$ This language and frame is one of private responsibility, rather than public accountability. ${ }^{21}$ The 'CSR rubric', as Burchell and Cook confirm, places 'the primary responsibility upon the voluntary actions of "good" companies rather than developing a regulatory framework. ${ }^{22}$ Its agenda is to allow businesses to develop their social and environmental strategies 'for themselves within a language of their own choosing'. ${ }^{23}$ As a consequence, the BHR agenda itself has been reframed in the process of implementation as one in which mandatory measures are eliminated as a part of a 'smart mix' of measures and presented as a hindrance to companies' voluntary CSR engagement.

Companies' resistance against BHR legislation is only one symptom of this more pervasive underlying reframing of the BHR agenda and an expression of what appears to be an ongoing process of co-optation. Selznick ${ }^{24}$ understood co-optation as a process of absorbing challenging elements into established decision-making structures with the purpose of aligning them with the organization's goals. Based on this, Burchell and Cook develop their own definition as 'the ability of the established political order to respond or accommodate new challenges and challengers without radically altering the foundations of the established political systems and processes.' ${ }^{25}$ The implication of such co-optation can be 'a de-radicalisation of the movements and a diluting of issues to accommodate them within the established political order.' ${ }^{26}$ More generally, social movement theorists perceive co-optation as the institutionalization of critique and protest through powerful groups in order to water down the demands and demobilize the opposition. ${ }^{27}$ In the context at hand, the domestication of challenging BHR demands comes with a reframing of those demands in less 'radical' terms, resulting in the assertion that the BHR agenda itself is better served if companies are trusted to find their own

\footnotetext{
20 Ibid, 7-8.

21 Florian Wettstein, "The history of "business and human rights" and its relationship with corporate social responsibility' in Surya Deva and David Birchall (eds.), Research Handbook on Human Rights and Business (Cheltenham: Edward Elgar, 2020); Anita Ramasastry, 'Corporate Social Responsibility Versus Business and Human Rights: Bridging the Gap Between Responsibility and Accountability' (2015) 14 Journal of Human Rights 237.

22 Jon Burchell and Joanne Cook, 'CSR, Co-optation and Resistance: The Emergence of New Agonistic Relations Between Business and Civil Society' (2013) 115 Journal of Business Ethics 741, 746.

23 Ibid, 746.

24 Philip Selznick, TVA and the Grass Roots: A Study in the Sociology of Formal Organizations (Berkeley, CA: University of California Press, 1949).

25 Burchell and Cook, note 22, 742.

26 Ibid, 742.

27 Dorothea Baur and Hans Peter Schmitz, 'Corporations and NGOs: When Accountability Leads to Co-optation' (2011) 106 Journal of Business Ethics 9.
} 
internal solutions voluntarily, rather than being forced through legislation. This view was expressed, for example, by the two large Swiss business associations SwissHoldings and economiesuisse in a statement aimed at clarifying their position on the RBI. The associations rejected the RBI based on the view that legislating human rights obligations of companies would amount to an imposition of governmental duties onto corporations. In their view, this would imply a redefinition of the UNGPs' envisioned distribution of responsibilities and thus be 'contrary to the spirit of the UNGPs'. At the same time, the two associations reiterated and reasserted their commitment to human rights and the UNGPs and stressed that their position 'does not conflict with [their] commitment to participating in further developing the agenda on business and human rights.' 28

The statement prompted a response by the author of the UNGPs, John Ruggie, who rebuked the associations for misconstruing the UNGPs, pointing out that mandatory measures are a part of the expectations expresses through them:

contrary to the letter's assertion, there is no inconsistency in states adopting measures that require businesses to meet their responsibility to respect human rights through legislation... Indeed, Guiding Principle 3 and its extensive commentary emphasize that states are expected to adopt a mix of measures - voluntary and mandatory, national and international - to foster business respect for human rights in practice. By doing so they [...] are doing what we expect governments to do: to govern, and to govern in the public interest. $^{29}$

Before attempting to make sense of this process of domestication, co-optation and confrontation that has characterized Pillar II implementation during the last decade, the following section will briefly outline and illustrate some of the key CSR-based arguments used in the context of the opposition against the RBI in Switzerland.

\section{A Case in Point: The Swiss Responsible Business Initiative}

A case in point of the process described in the previous section is the Swiss RBI. In 2015, a coalition of more than 100 non-governmental organizations (NGOs) launched the RBI with the aim of making it mandatory for Swiss companies to conduct human rights due diligence. ${ }^{30}$ The national referendum on the RBI took place in November 2020 and led to

\footnotetext{
28 SwissHoldings and economiesuisse, 'Letter to the Business and Human Rights Resource Centre' (13 September 2019), https://media.business-humanrights.org/media/documents/files/HL_2019-09-13_Letter_Business_and_Human_Rights_ Resource_Centre.pdf (accessed 1 April 2021).

29 John Ruggie, 'Letter to the Business and Human Rights Resource Centre' (19 September 2019), https://media.businesshumanrights.org/media/documents/files/documents/19092019_Letter_John_Ruggie.pdf (accessed 1 April 2021).

30 On the initiative as well as the parliamentary counter-proposal see, e.g., Nicolas Bueno, 'The Swiss Popular Initiative on Responsible Business: From Responsibility to Liability' in Liesbeth Enneking et al (eds.), Accountability, International Business Operations, and the Law: Providing Justice for Corporate Human Rights Violations in Global Value Chains (London: Routledge, 2019); Laura Knöpfel, 'The "Swiss Responsible Business Initiative" - an update', Business and Human Rights Journal Blog (12 June 2020), https://www.cambridge.org/core/blog/2020/06/12/the-swissresponsible-business-initiative-an-update/ (accessed 22 March 2021); Dalia Palombo, 'The Duty of Care of the Parent Company: A Comparison between French Law, UK Precedents and the Swiss Proposals' (2019) 4:2 Business and Human Rights Journal 265.
} 
a narrow rejection of the initiative. Consequently, a significantly weaker parliamentary counter-proposal will be put into law instead of the RBI. Most significantly, the counterproposal does not contain a liability clause. The RBI, on the other hand, would have held Swiss companies liable not only for their own conduct, but also for potential human rights violations committed by companies under their de facto control. ${ }^{31}$

The resistance of the private sector, as well as the government, against this initiative was fierce and CSR-based arguments also loomed large against it. In the following sections, I will briefly outline and discuss three such arguments.

\section{From CSR to Compliance}

A common argument against the RBI was that a human rights due diligence mandate would inevitably lead to a company internal reorganization of BHR-related issues and a respective shift from CSR departments to legal and compliance departments. The fear connected with this is that such a shift would replace the search for holistic, substantive solutions for BHR challenges with a legalistic compliance focus. ${ }^{32}$ Irrespective of the substance of this argument, which I will assess below, it seems important to point out that the argument in itself is a reflection of the domestication described above, as it is based on the assumption of CSR departments per se being the right place to situate the organization and coordination of BHR within the company. However, this seems at least questionable. After all, UNGP 23 states explicitly that companies should treat the risk of causing or contributing to gross human rights abuses as a legal compliance risk wherever they operate. This is despite the fact that the corporate responsibility to respect human rights is to be understood as expressly non-legal. The commentary to UNGP 23 points to the expanding web of mandatory legislation as one rationale for the importance of a compliance perspective. Thus, the enhanced role of legal and compliance departments was well-anticipated and not only welcomed but encouraged by the UNGPs. This being said, such shifts in internal organization are not dictated by natural law, but they are strategically planned and executed. Thus, such processes can be shaped and managed and it is precisely the role of CSR departments to create influence and leverage on such internal processes to enhance their responsiveness to matters concerning the social responsibility of companies. Thus, the argument that such organizational shifts happen entirely beyond CSR departments' 'sphere of influence' seems to prove all those critics right, who have argued all along that CSR constitutes a fig leaf without any tangible impact within organizations. In addition, recent research has pointed to the danger not of a legalization of corporate responsibility, but rather of a managerialization of legal compliance, that is, to a danger that compliance itself gets co-opted by, e.g., the business case logic of a CSR frame. ${ }^{33}$

\footnotetext{
31 See Palombo, note 25

32 Markus Huppenbauer, 'KONTRA: Was spricht philosophisch gegen die KOVI?' https://www.philosophie.ch/ blogartikel/highlights/philosophie-in-der-schweiz/konzernverantwortungsinitiative-pro-und-kontra/kontra-kovi (accessed 22 March 2021).

33 David Monciardini, Nadia Bernaz and Alexandra Andhov, 'The Organizational Dynamics of Compliance With the UK Modern Slavery Act in the Food and Tobacco Sector' (2021) 60:2 Business \& Society 288.
} 


\section{Tick-Box Compliance}

The second argument is a variation and substantiation of the first. The negative connotation attached to the above-mentioned shift from CSR to legal departments is not least based on a distinct view of compliance as strict 'letter of the law' or 'tick-box' compliance, which is focused narrowly on satisfying the legal requirements without any concern about whether the implemented measures actually generate any tangible impact on the situation of rights-holders on the ground. While this is often a problem and a sore spot of corporate compliance orientations, it is less an argument against BHR legislation per se, but rather one (a) against weak alibi mandates without any mechanisms that would prevent companies to take such short cuts and engage in purely cosmetic compliance ${ }^{34}$, and (b) against the compliance mentality of the company itself, which, similar to the argument above, can and should be shaped and managed. ${ }^{35}$ It is, after all, a company's choice how they respond to new legislation, whether they choose a substantive approach that indeed puts the rights-holders on the ground at the centre, or whether they follow a superficial tick-box approach, which only serves the mitigation of compliance risks for the company.

\section{Risk of Engagement}

Similar to the second argument, this third argument is a variation and a substantiation of the first. The argument is that sanctions, such as harsh penalties, but particularly civil or criminal liability could make it too risky for corporations to engage with local populations, as such engagement could be construed as proximity, which would increase liability risk for the corporations if things go wrong. In some instances, the risk to operate in certain high-risk areas may even be prohibitive and corporations may have to withdraw from such areas or countries only to be replaced with possibly even less responsible firms. ${ }^{36}$ Often such criticism is coupled with a reference to the Sustainable Development Goals (SDGs): if the risk for engagement is too high, then such BHR mandates undermine the possibility to work towards achievement of the SDGs. As such, they would prove counter-productive and may render the people worse off than before. In other words, the liability risk attached to BHR laws may undermine the CSR engagement and undermine efforts to achieve the SDGs precisely in those countries and regions, which are most dependent on it.

This argument has merit. However, two responses seem warranted. First, such a risk would increase particularly if a company would have to fear frivolous and baseless lawsuits, that is, lawsuits that are launched despite them having done what is needed to operate with all due care. However, considering the still tall financial, logistical and administrative obstacles that potential victims face in bringing lawsuits to the home states of companies, it is highly unlikely that legislation like the RBI would have significantly increased the risk of frivolous legal action against companies. The reverse case is still

\footnotetext{
34 Ingrid Landau, 'Human Rights Due Diligence and the Risk of Cosmetic Compliance' (2019) 20 Melbourne Journal of International Law 221; Monciardini, Bernaz and Andhov, note 33.

35 Lynn S Paine, 'Managing for Organizational Integrity' (1994) 72:2 Harvard Business Review 106.

36 Huppenbauer 2019, note 32.
} 
much more likely to happen. That is, lawsuits launched by companies to harass and silence human rights defenders. Such 'strategic lawsuits against public participation' (SLAPP) have become one of the most frequently used instruments of companies to deal with unwelcome critics. Thus, again, this objection merely holds against unsuitable formulations of BHR laws, rather than against BHR laws in principle. Second, the argument rests on a false dichotomy between the BHR and the SDGs regimes. Sustainable development and human rights improvement are not two separate and unrelated aims, but are interdependent and mutually reinforcing. As such, companies cannot convincingly support and work towards the achievement of the SDGs without making sure that human rights are respected in their operations and business relationships. Accordingly, enhancing corporate accountability is not an obstruction to, but a critical element of, achieving the SDGs. Indeed, provision of access to justice for all is prominently and expressly emphasized in SDG 16.

\section{Betting on the Wrong (Trojan) Horse}

We can make theoretical sense of the process of domestication, co-optation and confrontation by reference to long-standing critique against CSR advanced particularly in the domain of critical management studies.

Criticism towards CSR as a concept and practice has generally increased in recent years. Critics have questioned the effectiveness and impact of CSR and pointed to a growing trend of 'greenwashing' among companies, that is, of using CSR as a mere tool to enhance a company's reputation with little or no intention to change corporate practices substantively. ${ }^{37}$ From that perspective, CSR commitments remain just that, mere commitments, without having any tangible impact on 'business as usual' within the organization. Organizational theorists have theorized this as a process of 'decoupling', that is, a separation of well-meaning CSR policies on paper, from processes and practices with real impact on the ground. ${ }^{38}$

However, critical management scholars have gone a step further with their criticism of CSR. Decoupling, for them, is not a failure of CSR, but the essence of what it was meant to be all along. The purpose of CSR, as they argue, has never been to transform the corporation and the economy in order to put it on a path towards more sustainability. In their view, 'greenwashing' is the hidden agenda of CSR in order to legitimize and thus solidify the neoliberal capitalist agenda of free markets and the unregulated pursuit of corporate profits.

Thus, while classical liberals like Milton Friedman famously derided CSR as undermining a free society, ${ }^{39}$ his neoliberal successors understood that the expansion

\footnotetext{
37 Magali Delmas and Vanessa Cuerel Burbano, 'The Drivers of Greenwashing' (2011) 54:1 California Management Review 64.

38 John W Meyer and Brian Rowan, 'Institutionalized Organizations: Formal Structure as Myth and Ceremony' (1977) 83 American Journal of Sociology 340; Patricia Bromley and Walter W Powell, 'From Smoke and Mirrors to Walking the Talk: Decoupling in the Contemporary World' (2012) 6:1 Academy of Management Annals 483.

39 Milton Friedman, Capitalism and Freedom (Chicago: University of Chicago Press, 1962); Milton Friedman, 'The Social Responsibility of Business is to Increase its Profits', The New York Times Magazine (13 September 1970).
} 
of deregulated and free markets and thus a respective retreat of governments from market interference was only to be had by proposing an alternative to government oversight, which was to show that corporations were fit to fill the void by adopting social responsibility voluntarily. Thus, in neoliberalism, CSR turned from a perceived enemy of the free market into its very assurance. Against this background, it is not a coincidence either that the sharp rise of CSR's popularity particularly during the 1990s coincided with a period of unprecedented expansion of global markets. ${ }^{40}$ CSR, as Fleming and Jones suggest, is 'unwittingly wedded to a naturalized notion of Western neoliberal capitalism.' ${ }^{41}$ To make the reversal of roles complete, critique against CSR shifted from free market apologists like Friedman to those interested in an actual sustainable transformation of companies and the economy, who saw CSR as a 'tokenistic gesture' at best, but more likely as 'an alibi for business as usual, extending market forces even deeper into a social body that is already in seizure. ${ }^{42}$

Critical management scholarship has long pointed to this role of CSR as a key element of, and disguise for, the neoliberal project of expanding the liberalization and deregulation of markets worldwide. ${ }^{43} \mathrm{CSR}$, as they argue, was never meant to be a counter-force to free market ideology, but rather serves as an instrument to consolidate its totality: the expansion of free markets into an ever larger part of social life was to be accompanied and indeed facilitated by the transfer of social responsibility from the public into the private realm: 'Corporate social responsibility (CSR) does not represent a challenge to business. On the contrary, [...] CSR represents a further embedding of capitalist social relations and a deeper opening up of social life to the dictates of the marketplace. ${ }^{44}$

Against this background, critical management scholars have described CSR as a 'Trojan horse' whose purpose is precisely to 'co-opt criticism and deepen the current paradigm of global unsustainability.' 45 The instrumentalization of CSR to counter mandatory BHR measures fits seamlessly into this logic. The idea of CSR is not to reign in corporate unaccountability and impunity, but, on the contrary, to 'legitimize and consolidate the power of large corporations. ${ }^{46}$ Its role is to show that social justice is possible not despite, but through unfettered free market capitalism.

The popular idea of the so-called 'business case' for CSR is not only symptomatic, but defining for this 'colonization' ${ }^{47}$ of CSR by neoliberal free market ideology. The business

\footnotetext{
40 Archie B Carroll, Kenneth J Lipartito, James E Post, Patricia H Werhane and Kenneth E Goodpaster, executive editor, Corporate Responsibility: The American Experience (Cambridge, Cambridge University Press, 2012) 337-375.

41 Peter Fleming and Marc T Jones, The End of Corporate Social Responsibility (Los Angeles; London; New Delhi; Washington, DC: Sage, 2013) 3.

42 Ibid, 3.

43 Gerard Hanlon and Peter Fleming, 'Updating the Critical Perspective on Corporate Social Responsibility' (2009) 3:6 Sociology Compass 937.

44 Greg Hanlon, 'Rethinking Corporate Social Responsibility and the Role of the Firm - On the Denial of Politics' in Andrew Crane, Dirk Matten, Abagail McWilliams, Jeremy Moon and Donald S Siegel (eds.), The Oxford Handbook of Corporate Social Responsibility (Oxford: Oxford University Press, 2008) 156.

45 Fleming and Jones, note 41, 7.

46 Subhabrata Bobby Banerjee, 'Corporate Social Responsibility: The Good, the Bad and the Ugly' (2008) 43:1 Critical Sociology 51.

47 Fleming and Jones, note 41, 18.
} 
case for CSR is based on the idea that there is no conflict between profits and social responsibility; rather, there is a mutually reinforcing, almost symbiotic relationship between the two, in which social responsibility boosts profits and more profits enable the company to 'give back' to society. Against this background, greenwashing or decoupling are not isolated phenomena either, but a systematic part of this system and thus they have been identified as precisely one of the strategies of co-optation. It is of little surprise that such greenwashing strategies in particular are accompanied by fierce opposition against any attempt to make BHR requirements mandatory. ${ }^{48}$

\section{Conclusion}

That CSR may not be a suitable frame to advance business respect for human rights is not a new insight per se. ${ }^{49}$ In fact, BHR scholars have long argued that BHR should not be looked at as a variation or subset of CSR, but rather as a critical response to its perceived failure. ${ }^{50}$ Some may perceive such discussions on the differences and tensions between BHR and CSR as overly conceptual, academic hair-splitting. However, ten years into UNGPs implementation efforts, the practical manifestations of these differences are becoming acutely visible today.

Interestingly, the reactive stance of the majority of corporations on BHR legislation is increasingly countered also from within. A small, but growing number of companies have explicitly endorsed and spoken up for such legislation. For example, 26 businesses, among them large companies like Nestlé, H\&M and Unilever, have welcomed the announcement of the EU to enact new legislation on human rights due diligence. ${ }^{51}$ Such uniform cross-sectoral standards, as they argue, would harmonize expectations, increase legal certainty and clarify legal consequences in the case of non-compliance. Importantly, it would 'promote engagement and impactful action', ${ }^{52}$ rather than undercut it, as opponents of the RBI have argued. Similar statements of support were issued by company coalitions in the Netherlands in support of the new Dutch Child Labor Due Diligence Law, in Germany in support of a supply chain due diligence law, in Finland in support of a respective campaign for mandatory human rights due diligence legislation and in many other countries in which similar processes are currently under way. ${ }^{53}$

Such numbers are exceedingly small compared with the vast number of corporations, which have not voiced any support for BHR legislation or have actively opposed it. Nevertheless, the signalling effect of such support is significant

48 Frederick H Buttel, 'Environmentalism: Origins, Processes, and Implications for Rural Social Change' (1992) 57:1 Rural Sociology 1.

49 See, e.g., Robert McCorquodale, 'Corporate Social Responsibility and International Human Rights Law' (2009) 87 Journal of Business Ethics 385, 390-391.

50 Ramasastry, note 21; Wettstein, note 21.

51 ABN Amro et al, 'Support for EU framework on mandatory human rights and environmental due diligence' (2 September 2020), https://media.business-humanrights.org/media/documents/EU_Business_Statement_Mandatory_ Due_Diligence_02092020.pdf (accessed 11 April 2021).

52 Ibid.

53 For an overview, see https://www.business-humanrights.org/en/latest-news/list-of-large-businesses-associationsinvestors-with-public-statements-endorsements-in-support-of-mandatory-due-diligence-regulation/ 
and its impact on the public discussion should not be under-estimated. Precisely because of this apparent influence the question about their underlying motivation and agenda seems important.

However, the jury is out as to what drives such corporate engagement. On the one hand, it may indeed be an expression of corporations embracing a more political understanding of their human rights responsibility. It may well be that they have understood that corporate responsibility cannot be limited narrowly to private business conduct. Corporations are political institutions, whose corporate responsibility necessarily includes a political dimension; ${ }^{54}$ such advocacy in support of legislation is thus not beyond or even counter to a holistic understanding of corporate responsibility, but an integral part of it. ${ }^{55}$ After all, responsible business conduct in a competitive environment requires a floor of minimum standards for all companies. Thus, companies that are genuine with regard to their BHR commitments may have realized that levelling the playing field in this regard, helps, rather than undermines, their efforts. Taking a view on corporation-NGO interaction and distinguishing corporations with a strategic view on CSR from those with a political view on CSR, Baur and Schmitz argue that the latter understand the importance of accountability mechanisms and thus abstain from co-opting measures for their own sake. ${ }^{56}$

On the other hand, a gloomier interpretation may perceive their support itself as an expression of yet a further progression of the co-optation and capture of the public discussion on BHR. Coming to terms with the apparent inevitability of such legislation amidst the rapidly changing public perception towards the necessity of improved corporate accountability, it may be more beneficial for such corporations to actively influence and shape the discussion on what such laws will ultimately look like, rather than trying to block them altogether. After all, a weak business sponsored proposal may be what it takes to avoid much more far-reaching legislation as it is demanded by civil society organizations. Recent examples in Switzerland and Germany have shown clearly the danger of existing legislative proposals being watered down to a degree that their accountability gain ends up being minimal.

Either way, it should be emphasized here that BHR laws are not a silver bullet either. On their own, they certainly will not lead to the profound transformation that will end corporate impunity and unaccountability. The real force behind the shifting BHR landscape today are the civil society movements, which increasingly organize and mobilize across national borders in transnational ways and whose focus is on the longterm. Not the laws, but the movements behind them, will turn out as the key element to ensure that in thirty years from now, we are not looking back at BHR as just another fleeting episode in the hegemonic CSR success story.

\footnotetext{
54 Peter Ulrich, Integrative Economic Ethics. Foundations of a Civilized Market Economy (Cambridge: Cambridge University Press, 2008); Andreas G Scherer and Guido Palazzo, 'Toward a Political Conception of Corporate Responsibility: Business and Society Seen from a Habermasian Perspective' (2007) 32:4 Academy of Management Review 1096.

55 Florian Wettstein and Dorothea Baur, “"Why Should We Care about Marriage Equality?”: Political Advocacy as a Part of Corporate Responsibility' (2016) 138 Journal of Business Ethics 199.

56 Baur and Schmitz, note 27, 18.
} 